msh-mss Mathématiques et sciences humaines

134 | Été 1996

Varia

\title{
Comparaison de tendance centrale par l'analyse des transferts
}

Comparison of central tendencies by means of transfer analysis

\section{Eric Terouanne}

\section{(2) OpenEdition \\ 12 Journals}

Édition électronique

URL : http://journals.openedition.org/msh/2726

DOI : $10.4000 / \mathrm{msh} .2726$

ISSN : 1950-6821

Éditeur

Centre d'analyse et de mathématique sociales de l'EHESS

Édition imprimée

Date de publication : 1 mars 1996

ISSN : 0987-6936

Référence électronique

Eric Terouanne, "Comparaison de tendance centrale par l'analyse des transferts », Mathématiques et sciences humaines [En ligne], 134 | Été 1996, mis en ligne le 10 février 2006, consulté le 23 juillet 2020 URL : http://journals.openedition.org/msh/2726 ; DOI : https://doi.org/10.4000/msh.2726

Ce document a été généré automatiquement le 23 juillet 2020

(c) École des hautes études en sciences sociales 


\title{
Comparaison de tendance centrale par l'analyse des transferts
}

\author{
Comparison of central tendencies by means of transfer analysis
}

\section{Eric Terouanne}

\section{RÉSUMÉS}

La différence de tendance centrale entre deux distributions sur un ensemble fini est représentée par une série de transferts entre les modalités. Un modèle unique est proposé qui permet d'analyser ces différences pour des variables nominales, ordinales ou métriques aussi bien que pour les variables numériques. En particulier on définit un indice de différence entre les distributions qui se ramène à l'indice de distorsion de Gini dans le cas d'une variable nominale et à la différence entre les moyennes dans le cas d'une variable numérique.

The differences in the central tendency of two distributions on a finite set is represented by a series of transfers between modalities. A common model is presented which allows one to analyze these transfers for nominal, ordinal or metric variables, as well as for numerical ones. In particular, we define an index of difference between the distributions which boils down to Gini's distortion index in the case of a nominal variable and to the difference between the means in the case of a numerical variable.

\section{INDEX}

Thèmes : concentration, distances, données (analyse des), mesure - mesurage, ordres et préordres, statistique 